\title{
Changes in Diets of Wapiti during a Hunting
}

Season

LUIGI E. MORGANTINI AND ROBERT J. HUDSON

\section{Abstract}

This study was conducted to assess the impact of hunting on diets of a wapiti (Cervus elaphus) population in west-central Alberta, Canada. During special winter hunts, consumption of rough fescue (Festuca scabrella) decreased from $86.9 \%$ to $34.3 \%$, while browsing increased. The contribution of wild rye (Elymus innovatus) and wheatgrass (Agropyron subsecundum), mostly growing in forested areas, increased 15-18\%. After the hunting seasons, animals returned to the same diet they had selected previously. Browse had significantly higher crude protein contents, but lower dry matter digestibility than grasses. In spite of submaintenance crude protein contents of grasses, undisturbed wapiti appeared to prefer grazing to browsing.

The potential impact of human activities on wapiti (Cervus elaphus) has received considerable attention. Several authors have reported changes in distribution, habitat selection, and behavioural patterns caused by recreational or industrial activities (Ward et al. 1973, Perry and Overly 1976, Lyon 1979). Attempts also have been made to relate levels and types of human disturbance to energy expenditures (Ward et al. 1976). However, an assessment of the impact of human activities on welfare and productivity of ungulate populations is still limited to approximate determinations of habitat loss and to general statements about consequences of altered distribution patterns. Morgantini and Hudson (1979) reported the avoidance of traditional ranges by wapiti during winter hunting seasons. This report documents a major change in food habits accompanying this redistribution.

\section{Study Area and Methods}

The study was conducted on the Ya Ha Tinda Ranch, a traditional winter range in west central Alberta, Canada. The area, 35 $\mathrm{km}^{2}$, is located in the foothills of the Rocky Mountains, approxi-

Authors are respectively, president, Wildland Resources Consultants, and associate professor, Department of Animal Science, University of Alberta, Edmonton, Canada, T6G 2P5. At the time of the study, the senior author was graduate research assistant with the University of Alberta.

We thankfully acknowledge the financial support of the Alberta Fish and Wildlife Division and the cooperation of Parks Canada.

Manuscript accepted April 17, 1984. mately $10 \mathrm{~km}$ east of Banff National Park. It consists of a rolling open rough fescue (Festuca scabrella) grassland surrounded by aspen (Populus tremuloides) and lodgepole pine (Pinus contorta) forests. Willows (Salix spp.) and dwarf birch (Betula glandulosa) are abundant in the grassland-forest ecotone. Due to the surrounding mountains, the area is subject to mild winter weather while westerly winds keep grasslands largely snow-free.

At the time of the study, 1976-77 and 1977-78, approximately 400 animals wintered in the valley. Most were cows and calves with a few young bulls. These animals comprised a major portion of the wapiti inhabiting the northern half of Banff National Park.

Between 1969 and 1975 , in response to presumed overgrazing, special hunting seasons (either sex) were held during the first 2 weeks of January and February. Hunting was allowed only 3 days a week. From 1976 to 1978 , the special season was restricted to males. Every winter 200 licenses were issued, 50 for each week of the hunt.

This study focused on food habits prior, during, and after the hunting seasons of 1977 and 1978. Diet composition was estimated by identification of plant cuticular fragments in feces (Hansen et al. 1973, Dearden et al 1975). Every month, 20 samples of fresh wapiti pellets were collected. During the hunting season, pellet collection was restricted to the last day of the hunt to allow sufficient time for forage passage through the digestive tract (Uden 1978). During the winter of 1977 , the late arrival of animals on winter range in December did not allow fecal collection before hunting. Also, samples could not be collected during the February hunts of 1977 since high hunting harassment forced animals to abandon the entire area and seek refuge on alpine ranges and in Banff National Park.

Approximately $5 \mathrm{~g}$ from each oven-dried sample were combined into one composite sample representing monthly diets. These were sent to the Composition Analysis Laboratory, Colorado State University, for analysis at $\mathbf{1 0 0}$ microscope fields per sample.

To assess forage quality, composite grassland forage samples were collected during the winter of 1977-78 from 10 randomly distributed $20 \times 50-\mathrm{cm}$ plots. Composite samples were considered adequate for this study because of the homogeneous plant composition of the winter range (McGillis, J.W. 1977. unpublished 
report) and the uniform grazing pattern of undisturbed wapiti (Morgantini and Hudson 1979). Willow samples were collected along the edge of the open range and were limited to current annual growth.

Crude protein (CP) was assessed using the macro-Kjeldahl method (AOAC 1965). In vitro digestible dry matter (IVDDM) was determined following Tilley and Terry (1963) and Minson and McLeod (1972). The technique was modified by placing vials with forage samples and rumen inoculum in an incubation room maintained at $38^{\circ} \mathrm{C}$. Constant stirring was achieved with a flask shaker $(160 \mathrm{rpm})$. Monthly samples were combined into one composite sample on which one IVDDM trial was conducted in triplicate. Rumen inoculum was obtained from a fistulated wapiti steer maintained on a diet consisting of a pelleted aspen-barley concentrate, chopped alfalfa, and browse. The animal had access to tame grass pasture ad libitum.

\section{Results and Discussion}

The contribution of major plant groups to the diet of wapiti during mid-winter hunts is compared with results before and after hunting in Table 1. During the winter of 1976-77, consumption of

Table 1. Diets of wapiti during hunting (January 1977 and January and February 1978) and non-hunting periods (February and March 1977, December 1977 and March 1978). Percentage fecal composition.

\begin{tabular}{|c|c|c|c|c|}
\hline & \multicolumn{2}{|c|}{ Hunting periods } & \multicolumn{2}{|c|}{ Non-hunting periods } \\
\hline & $\mathrm{x}$ & SE & $\mathrm{x}$ & SE \\
\hline \multicolumn{5}{|l|}{ Grasses } \\
\hline Elymus-Agrop. & $18.3 \mathrm{a}$ & 1.5 & $.8 \mathrm{~b}$ & .3 \\
\hline Festuca spp. & $34.3 \mathrm{a}$ & 7.5 & $86.9 b$ & 1.9 \\
\hline Others & $5.3 \mathrm{a}$ & 2.1 & $1.1 \mathrm{~b}$ & .6 \\
\hline Total grasses & $57.9 \mathrm{a}$ & 4.7 & $88.8 b$ & 1.7 \\
\hline \multicolumn{5}{|l|}{ Sedges } \\
\hline Carex spp. & $10.2 \mathrm{a}$ & 7.4 & $3.5 \mathrm{~b}$ & .4 \\
\hline Others & 1.1 & .7 & .2 & .1 \\
\hline Total sedges & $11.3 \mathrm{a}$ & 1.8 & $3.7 \mathrm{~b}$ & .4 \\
\hline \multicolumn{5}{|l|}{ Shrubs \& Trees } \\
\hline Salix spp. & $16.0 \mathrm{a}$ & 5.8 & $1.9 \mathrm{~b}$ & .7 \\
\hline Pinus spp. & 5.8 & 2.9 & 1.8 & .5 \\
\hline Others & 6.4 & 4.5 & 1.0 & .4 \\
\hline Total shrubs \& trees & $28.3 \mathrm{a}$ & 4.8 & $4.7 \mathrm{~b}$ & .8 \\
\hline Forbs & 2.2 & .9 & .27 & 1.5 \\
\hline
\end{tabular}

'Values within rows followed by different letters are significantly different at $P<0.05$.

grasses increased after the hunting season from $66.0 \%$ to $85.6 \%$. The following winter, grasses decreased from $84.7 \%$ to $50.5 \%$ during hunting and increased again to $88.2 \%$ afterwards.

Further insight is obtained from examination of the dietary contributions of individual species. Use of fescue during the January hunts was substantially less than the month preceding or following. During both winters, consumption of hairy wild rye (Elymus innovatus) and bearded wheatgrass (Agropyron subsecundum), increased from about $1 \%$, outside the hunting seasons, to 15 and $18 \%$ of the diet during hunting.

These results reflect the pattern of animal distribution and habitat selection described by Morgantini and Hudson (1979) for the winter preceding this study. The significant decrease in dietary contribution of fescue reflects avoidance of open grasslands. Greater utilization of wild rye and wheatgrass is associated with increased use of surrounding aspen forests, where the winter herbaceous layer is composed mostly of hairy wild rye and bearded wheatgrass. The higher level of browsing during hunting is related to increased utilization of edge habitats supporting dense stands of willow (Morgantini and Hudson 1979).

On the Ya Ha Tinda winter, range grasses, specifically rough fescue, normally dominate wapiti diets. However, rough fescue is a nutritionally poor forage in winter. Crude protein content at a weathered stage is reported to be $4.2 \%$, well below minimum maintenance requirements of range cattle (Johnston and Bezeau 1962). Crude protein content of rough fescue in the study area in December 1982 was 2.6\% (Morgantini, L.E. 1983. unpublished data). Crude protein content of composite range samples collected during this study (1977-78) averaged between $3.1( \pm 0.14)$ and $3.7 \%$ $( \pm 0.16)$ of dry matter (Table 2 ).

Table 2. In vitro dry matter digestibility (IVDDM) and crude protein (CP) of composite range samples and wlllow twigs during the winter of 1977-78.

\begin{tabular}{lll}
\hline \hline & Grasses \% & Willow \% \\
\hline IVDDM & & \\
December & 68.5 & 50.7 \\
January & 67.0 & 50.0 \\
February & 67.2 & 54.2 \\
March & 67.3 & 51.3 \\
x \pm SE & $67.5 \mathrm{a} \pm 0.331$ & $51.6 \mathrm{~b} \pm \mathbf{0 . 9 2}$ \\
CP & & \\
December & 3.6 & 8.4 \\
January & 3.7 & 8.9 \\
February & 3.5 & 8.5 \\
March & 3.1 & 9.2 \\
x \pm SE & $3.5 \mathrm{a} \pm 0.13$ & $8.7 \mathrm{~b} \pm 0.18$ \\
\hline
\end{tabular}

IValues within rows followed by different letters are significantly different at $P<0.05$.

Dietary protein requirements for wapiti in winter are believed to range between $7 \%$ and $5 \%$ (Hobbs et al. 1981). Even though wapiti wintering on the Ya Ha Tinda Ranch may select for parts of plants with a higher protein content, it is unlikely that selectivity fully compensates for a forage species that is such a poor source of nitrogen. The shift to wild rye and wheatgrass, observed during the hunting seasons, did not significantly increase the intake of nitrogen per unit of dry matter. Crude protein content of hairy wild rye and wheatgrass at a weathered stage is reported to be $2.08 \%$ and $2.10 \%$, respectively (Johnston and Bezeau 1962). In the winter of 1982-83, crude protein content of wheatgrass near the Ya Ha Tinda Ranch area averaged 3.1\% (Morgantini and Russel 1984, unpublished report).

Crude protein content of willow twigs ranged from $8.4 \%( \pm 0.15)$ in December 1977 to 9.2\% ( \pm 0.3 ) in March, 1978(Table 2). During winter, browse species generally retain higher amounts of digestible protein than grasses (Cook 1972). Therefore, a significant increase of willow in the diet of wapiti might appear to be nutritionally beneficial. However, in view of the significantly lower IVDDM of willow twigs, the shift to browsing decreased the concentration of digestible energy.

The feeding behaviour of wapiti on the Ya Ha Tinda ranch does not conform to the feeding strategy of wapiti in Colorado where animals shifted to browse in response to low nitrogen content of grasses (Hobbs et al. 1981). In spite of the low nitrogen content of grasses on the Ya Ha Tinda Ranch, willow did not make up a major portion of the diet outside the winter hunting seasons. Higher IVDDM content of grasses in our study area (67-68\%) than in Colorado (44-45\%; Hobbs et al. 1981) may explain the absence of such compensatory feeding behavior.

According to Ammann et al. (1973), most ruminants have difficulty consuming enough forage to meet energy requirements when digestible dry matter falls below $50 \%$. In this study, willow twigs barely met requirements, whereas IVDDM values of grasses exceded this approximate criterion by a significant margin. The observed preference by undisturbed wapiti of grasses over browse suggest that digestibility is more critical to wintering wapiti than nitrogen. Nitrogen requirements may be partially met by either increased intake and/or more efficient nitrogen recycling (Mould 
and Robbins 1981).

We conclude that special winter hunting seasons cause a major shift in diet selection and that this shift resulted in lower diet digestibility. Crude protein content in the diet increased but the net effects of the increase are unclear. Nonetheless, it is reasonable to assume that during severe winters, when digestible energy is probably most limiting, a decrease of its dietary concentration would have a negative impact on the welfare of wapiti populations in west-central Alberta.

\section{Literature Cited}

A.0.A.C. 1965. Official methods of analysis. 10th ed. Ass. Off. Agr. Chemists, Washington, D.C.

Ammann, A.P., R.L. Cowan, C.L. Mothershead, and B.R. Baumgardt. 1973. Dry matter and energy intake in relation to digestibility in whitetailed deer. J. Wildl. Manage. 37:195-201.

Cook, C.W. 1972. Comparative nutritive values of forbs, grasses and shrubs. p. 303-310. In:C.M. McKell, J.P. Blaisdell and J.R. Goodin, eds. Wildland shrubs: their biology and utilization. USDA Gen. Tech. Rep. INT-1.

Dearden, B.L., R.E. Pegau, and R.M. Hansen. 1975. Precision of microhistological estimates of ruminant food habits. J. Wildl. Manage. 39:402-407.

Hansen, R.M., D.G. Peden, and R.W. Rice. 1973. Discerned fragments in feces indicates diet overlap. J. Range Manage. 26:103-105.

Hobbs, N.T., D.L. Baker, J.E. Ellis, and D.M. Swift. 1981. Composition and quality of elk winter diets in Colorado. J. Wildl. Manage. 45:156-171.
Johnston, A., and L.M. Bezeau. 1962. Chemical composition of range forage plants of the Festuca scabrella association. Can. J. Plant Sci. 42:105-115.

Lyon, L.J. 1979. Habitat effectiveness for elk as influenced by roads and cover. J. Forest. 77:658-660.

Minson, D.J. and M.N. MeLeod. 1972. The in vitro technique: its modification for estimating digestibility of large numbers of tropical pasture samples. Division of Tropical Pastures Technical Paper No. 8. C.S.I.R.O. Australia

Morgantini, L.E., and R.J. Hudson. 1979. Human disturbance and habitat selection in elk. p. 132-139. In: North American elk: ecology, behavior, and management, ed. M.S. Boyce and L.D. Hayden-Wing, Laramie: Univ. Wyoming.

Mould, E.D., and C.T. Robbins. 1981. Nitrogen metabolism in elk. J. Wildl. Manage. 45:323-334.

Perry, C., and R. Overy. 1976. Impacts of roads on big game distribution in portions of the Blue Mountains of Washington. p. 62-68. In: Proc. Elk-Logging-roads symp., ed. S.R. Hieb, Moscow: Univ. Idaho.

Tilley, J.M.A., and R.A. Terry. 1963. A two stage technique for the in vitro digestion of forage crops. J. Br. Grassl. Soc. 18:104-111.

Uden, P. 1978. Comparative studies on rate of passage, particle size and rate of digestion in ruminants, equines, rabbits and man. Ph.D. Thesis. Cornell University, Ithaca, N.Y.

Ward, A.L., J.J. Cupal, A.L. Lea, C.A. Oakley, and R.W. Weeks. 1973. Elk behavior in relation to cattle grazing, forest recreation, and traffic. Trans. N. Amer. Wildl. and Natur. Resour. Conf. 38:327-337.

Ward, A.L., J.J. Cupal, G.A. Goodwin and H.D. Morris. 1976. Effects of highway construction and use of big game populations. Rep. No. FHWA-RD-76. Washington, D.C., Fed. Highway Admin. 